\title{
Long time hidden: second record in the type locality and redescription of rare caridean shrimp Lebbeus uschakovi (Kobjakova, 1936) (Crustacea: Decapoda: Thoridae)
}

\section{Аиительное время в безвестности: вторая находка в типовом местонахождении и переописание редкого вида каридной креветки Lebbeus uschakovi (Kobjakova, 1936) (Crustacea: Decapoda: Thoridae)}

\author{
Sergey E. Anosov ${ }^{1}$, Boris G. Ivanov ${ }^{1 \dagger}$, Vassily A. Spiridonov ${ }^{2}$ \\ С.Е. Аносов ${ }^{1}$, Б.Г. Иванов ${ }^{1 \dagger}$, В.А. Спиридонов ${ }^{2}$

\footnotetext{
${ }^{1}$ Russian Federal Institute of Fishery and Oceanography (VNIRO), Verkhnyaya Krasnoselkaya, 17a, Moscow 107140 Russia. E-mail: florarium@gmail.com

2 Shirshov Institute of Oceanology of Russian Academy of Sciences, Nakhimovskiy Prospekt, 36, Moscow 117997 Russia. E-mail: vspiridonov@ocean.ru

${ }^{1}$ Всероссийский институт рыбного хозяйства и океанографии (ВНИРО), Верхняя Красносельская, $17 \mathrm{a}$, Москва 107140 Россия.

${ }^{2}$ Институт океанологии им. П.П. Ширшова Российской академии наук, Нахимовский проспект, 36, Москва 117997 Россия.
}

KEY WORDS: Endemic species, Sea of Okhotsk, Iona Bank, hard bottom, epifauna.

КЛЮЧЕВЫЕ СЛОВА: Эндемичный вид, Охотское море, банка Ионы, твердые субстраты, эпифауна.

ABSTRACT. Lebbeus uschakovi (Kobjakova, 1936), known until now only upon the type specimens (type locality near Iona I. in the north-western Sea of Okhotsk) is redescribed on the basis of an extant female syntype and a new specimen (female) collected in the type locality in 2017. Lectotype (deposited in the Zoological Institute of Russian Academy of Science, St. Petersburg) is designated. A characteristic coloration pattern is illustrated. L. uschakovi belongs to the group of Lebbeus species with epipods present on the $3^{\text {rd }}$ maxilliped and three anterior pereiopods, moderate to relatively long rostrum, and smooth margins of pleura $1-3$. The species of this group are known from restricted localities at the North-West Pacific shelf, the continental slope of East Pacific, the continental slope of North Africa, seamounts in the southwestern Indian Ocean, and the deep Bali Sea. $L$. uschakovi has large eggs which size indicates an abbreviated larval development and a limited dispersal capacity of larvae. It occurs in specific hard bottom low-subtidal biotopes with complete mixing of the water column, strong near bottom currents and rich epifauna. Since not many such biotopes outside the type locality at the Iona Bank are known in the Sea of Okhotsk and none are expected in the neighboring waters of East Kamchatka and the northern Sea of Japan, L. uschakovi likely represents a true Sea of Okhotsk endemic species.

How to cite this article: Anosov S.E., Ivanov B.G., Spiridonov V.A. 2018. Long time hidden: second record in the type locality and redescription of rare caridean shrimp Lebbeus uschakovi (Kobjakova, 1936) (Crusta- cea: Decapoda: Thoridae) // Arthropoda Selecta. Vol.27. No.1. P.37-48. doi: 10.15298/arthsel. 27.1.05

РЕЗЮМЕ. Lebbeus uschakovi (Kobjakova, 1936), известный до настоящего времени только по типовым экземлярам из района о. Ионы, расположенного в северо-западной части Охотского моря, переописан на основе сохранившегося синтипа (самки) и новой находки (также самки) в районе типового местообитания в 2017 г. Обозначен лектотип вида, хранящийся в Зоологическом институте $\mathrm{PAH}$, Санкт-Петербург. Иллюстрирована характерная окраска вида. L. uschakovi принадлежит к группе видов рода, которые характеризуются наличием эпиподитов на максиллипедах 3-й пары и первых трех парах перейопод, умеренно развитым или длинным рострумом и гладкими краями плевр 1-3-го абдоминальных сегментов. Виды, относящиеся к этой группе, известны из отдельных местообитаний на шельфе северо-западной Пацифики, материкового склона Восточной Пацифики, материкового склона Северной Африки, подводных гор юго-западной части Индийского океана и батиали моря Бали. Для L. uschakovi характерны крупные яйца, что предполагает укороченное личиночное развитие и ограниченные возможности распространения личинок. Вид обитает в специфических нижне-сублиторальных биотопах с твердыми грунтами, полным перемешиванием водной толщи, сильными придонными течениями и богатой эпифауной. Подобных биотопов, сходных с типовым местообитанием на банке Ионы, в Охотском море известно не так уж мно- 


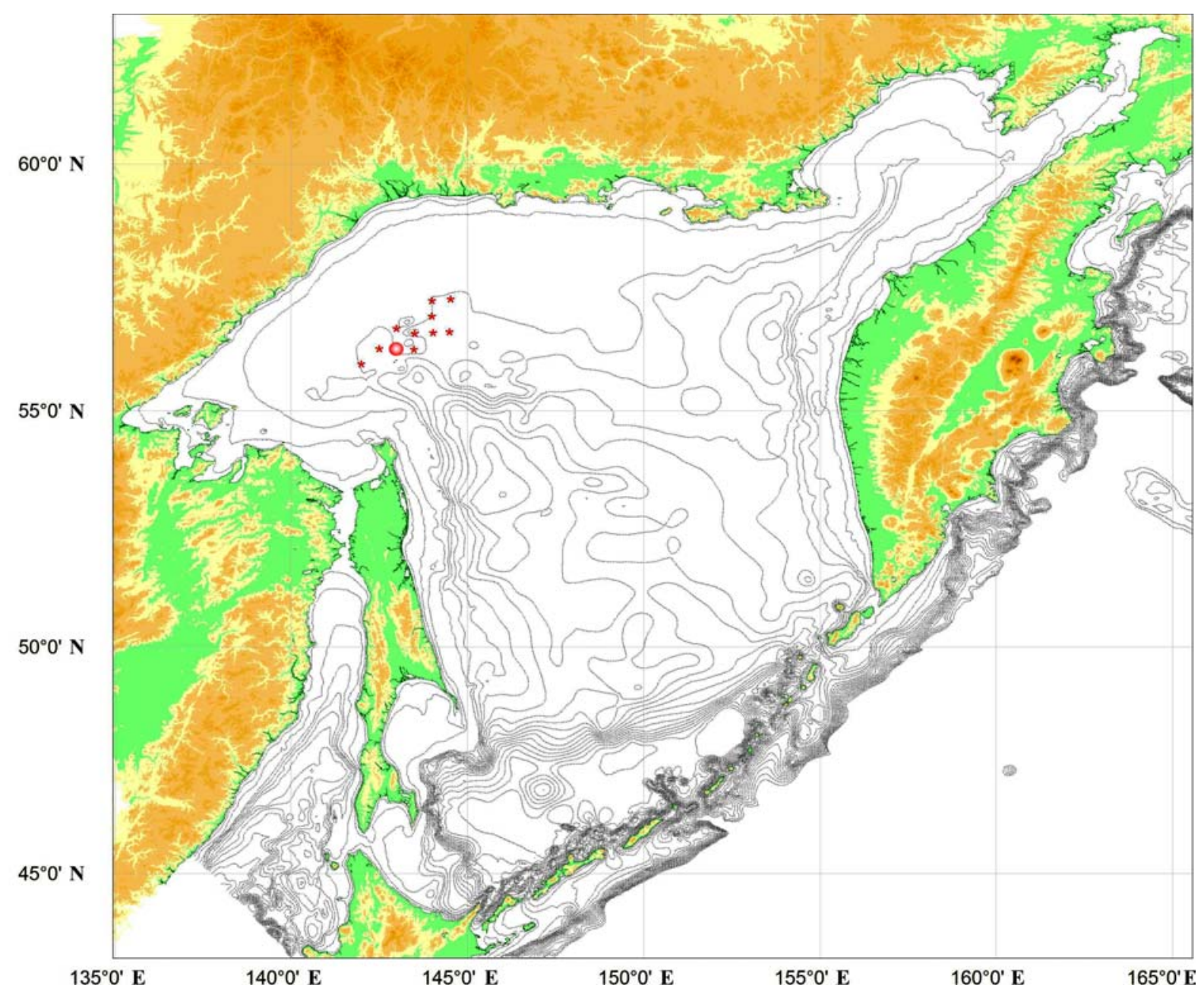

Fig. 1. Exploratory trawling of F/V "Asanda" around Iona Bank, Sea of Okhotsk in August 2017. Locality of Lebbeus uschakovi records in 1932 and 2017 is shown by a circle. Depth contours shown with a $100 \mathrm{~m}$ intervals.

Рис. 1. Поисковые траления, выполненные на СКТР «Асанда» в районе банки Ионы, Охотское море в августе 2017. Кружком показано местонахождение Lebbeus uschakovi в 1932 и 2017 гг. Изобаты проведены через 100 м.

го, а в соседних районах Юго-восточной Камчатки и северной части Японского моря они не известны. Таким образом, L. uschakovi весьма вероятно является настоящим эндемиком Охотского моря.

\section{Introduction}

The Sea of Okhotsk has a rich fauna of the decapod crustaceans comprising of about 135 species [Spiridonov et al., 2013; for additions see Komai, 2015]. A significant fraction of these species was originally described from various parts of the sea as type localities by Brandt [1851], Brazhnikov [1907], Kobjakova [1936, 1937, 1955, 1962], Birstein \& Vinogradov [1951], Komai \& Eletskaya [2008], and Komai [2015]. Many of early (XIX to mid-XX century) described species have been later found elsewhere in the North Pacific [Kobjakova, 1936, 1937, 1955, 1962; Vinogradov, 1950; Butler, 1980; Hayashi, 1992; Komai, Komatsu, 2009; Marin, 2013; Spiridonov et al., 2013;
Bandurin, Karpinsky, 2015]. Some rare, briefly described, or seemingly ambiguous species have been redescribed on the basis of either type specimens [Komai, 1997] or new material [Komai, Amaoka, 1989; Komai, Yakovlev, 2000; Komai et al., 2016] while some species remain known only from type localities and original descriptions. These in particular include Lebbeus uschakovi (Kobjakova, 1936) (originally described as Hetairus uschakovi) that until now have been only known upon the type specimens found near Iona I. in the north-western Sea of Okhotsk. As Kobjakova's [1936, 1937] description is brief and does not provide details and illustrations of several characters that are currently used in the caridean taxonomy, the species has been long time desired to be redescribed [Hayashi, 1992; Fransen, 1997; Komai et al., 2016]. This is particularly important for documenting diversity, and clarifying taxonomy of the genus Lebbeus White, 1847. This genus appears to be highly diverse, currently including 68 species group taxa: 66 accepted species 


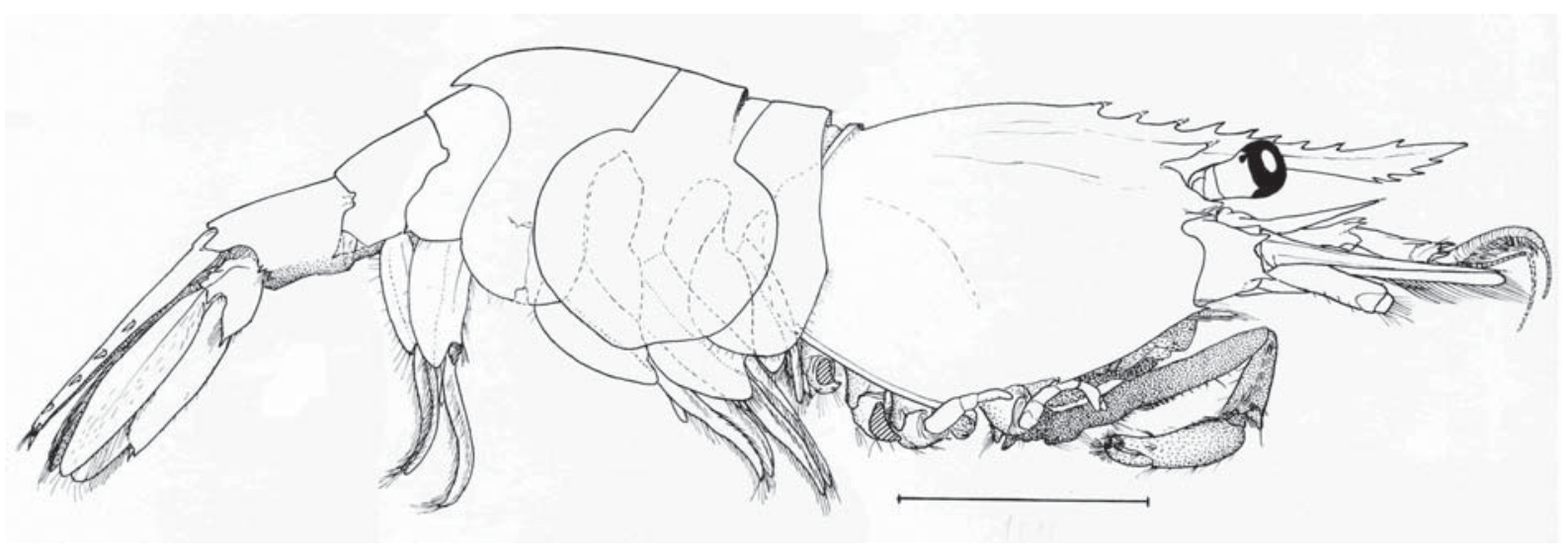

Fig. 2. Lebbeus uschakovi (Kobjakova, 1936). Lectotype, female (ZIN-RAS 1/47346), general appearance. Drawing by B.G. Ivanov. Рис. 2. Lebbeus uschakovi (Kobjakova, 1936). Лектотип, самка (ЗИН РАН 1/47346), общий вид. Рисунок Б.Г. Иванова.

and 1 subspecies [De Grave, Fransen, 2011; Komai, 2013, 2015; Komai et al., 2012; Nye, 2013; Nye et al., 2013; Matsuzaki et al., 2015; Schiaparelli et al., 2015; Chan, Komai, 2017; WORMS, 2018], and Lebbeus pauli Brandt, 1851 which is distinct but largely overlooked species [Menshutkina, 1987], not listed in WORMS (2018). Lebbeus spp. shows interesting biogeographical patterns [Fransen, 1997; Nye, 2013; Schiaparelli et al., 2015; Komai et al., 2016], demonstrate cases of symbiosis [Jonsson et al., 2001; Schiaparelli et al., 2015], and association of some species with hydrothermal biotopes [Nye et al., 2013], cold seeps [Chan, Komai, 2017], and whale carcasses on the bottom [Nye, 2013].

The authors, first B.G. Ivanov (1937-2006) in the 1980-90s, and recently V.A. Spiridonov and S.E. Anosov have undertaken a project of redescription of the North Pacific decapods types (including Hetairus uschakovi) deposited in the Zoological Institute of Russian Academy of Sciences in St. Petersburg (ZIN RAS). A new specimen of this species has been recently collected very close to the type locality in the course of fishery research in the Sea of Okhotsk by the first author. The present communication presents a redescription of Lebbeus uschakovi based on both re-examination of the type material and examination of the newly recorded specimen.

\section{Material and methods}

The new material was collected in the course of exploratory trawl survey performed by F/V "Asanda" around the Iona Bank, near Iona I. (also spelled as St. Iona I.) in the Sea of Okhotsk. Thirteen trawl hauls were conducted within the area between $55^{\circ} 51^{\prime} \mathrm{N}-$ $57^{\circ} 13^{\prime} \mathrm{N}$ and $142^{\circ} 14^{\prime} \mathrm{E}-144^{\circ} 47^{\prime} \mathrm{E}$ at the depth range between 137 and $350 \mathrm{~m}$ (Fig. 1) using a commercial shrimp trawl with a selective device. The catch was inspected, representative specimens of all collected decapods species, and all specimens of non-common species were photographed and fixed in $96 \%$ ethanol for subsequent morphological and molecular genetic studies. One trawling was performed at approximate location where Lebbeus uschakovi had been collected, according to the information provided by Kobjakova [1937] and Ushakov [1952]. In the catch of this haul $L$. uschakovi was recorded for the second time, 85 years past the first record.

An initial re-examination of the holotype of the studied species in the Zoological Institute of Russian Academy of Science (ZIN RAS) was done by B.G. Ivanov in the 1980s. Drawings and hand-written notes from his archive in the Laboratory of Commercial Invertebrates of VNIRO have been used for preparation of the redescription of the species based on both the holotype and the newly collected specimen (deposited in the Zoological Museum of the Moscow University, ZMMU). Morphological terminology used in the description follows McLaughlin [1980, fig. 45] (with acceptance of the term "pleon and pleomeres" instead of "abdomen and abdominal segments") and Nye et al. [2013] with an addition concerning the preanal spine and adjacent areas of the pleomere 6 [Spiridonov, 1993].

All measurement [according to Menshutkina, 1987] were done using a caliper with accuracy of $0.1 \mathrm{~mm}$. The following abbreviation are used in text: CL1 - carapace length from the margin of the orbit to the posterodorsal margin; CL2 carapace length from the anterolateral margin to posterolateral margin; $\mathrm{CH}$ - maximum carapace height; P1-P5 pereiopods $1-5, \mathrm{RL}$ - rostrum length; TL - total length from the tip of rostrum to the posterior margin of telson.

\section{Systematic account}

Order Decapoda Latreille, 1802

Suborder Pleocyemata Burkenroad, 1963 Infraorder Caridea Dana, 1852

Superfamily Alpheoidea Rafinesque, 1815

Family Thoridae Kingsley, 1879

Lebbeus uschakovi Kobjakova, 1936

Figs 2-6.

Hetairus uschakovi Kobjakova, 1936: 222, fig, 11.

Hetairus uschakovi - Kobjakova, 1937: 114, Pl. III, fig. 18. 


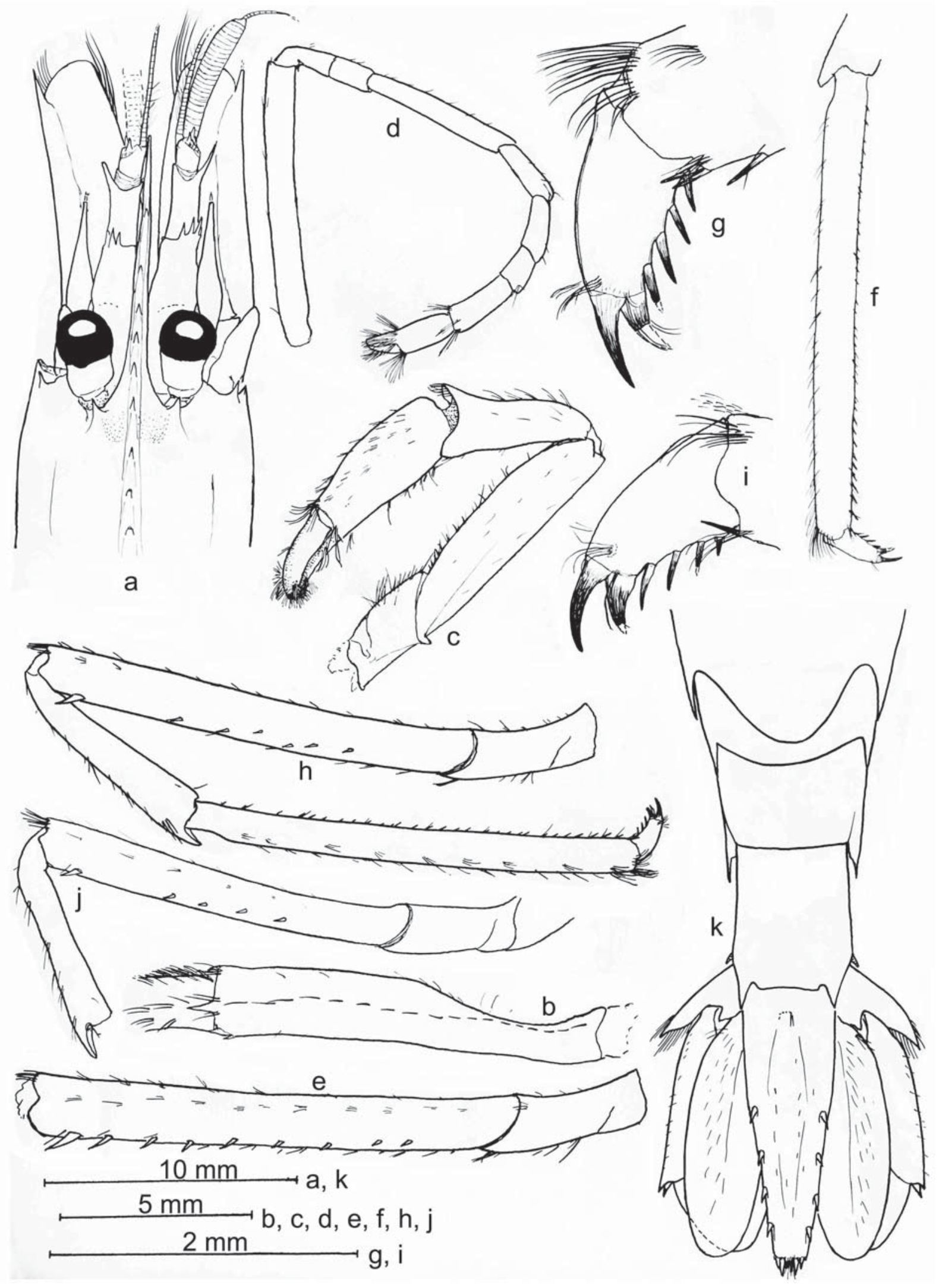


Lebbeus uschakovi - Hayashi, 1992: 112 (key).

Lebbeus ushakovi — De Grave, Fransen, 2011: 427 (list). Bandurin, Karpinsky, 2015: 42 (key).

TYPE MATERIAL. 1 female (ZIN-RAS 1/47346), Sea of Okhotsk, RV “Gagara", Station 248, 182 m, 19.08.1932, beamtrawl, coll. P.V. Ushakov, det. Z.I. Kobjakova. The inscription "Holotype" in the upper right angle of the label. In the paper with more detailed description of her new species, Kobjakova [1937] indicated that there were two ovigerous females collected at Stat. 248. As there were originally two specimens upon which the species had been described, and the holotype was not designated in the original publication, the present specimen had to be regarded syntype [International Commission, 1999]. The female deposited in ZIN-RAS does not have eggs which remain attached to pleopods, but about 180 eggs are present in the jar. The specimen is damaged; on the right side only $\mathrm{P} 1$ and $\mathrm{P} 3$ (as a small regenerating appendage) are present (Fig. 2), maxilliped 3 and other pereiopods are missing; separate left appendages present: broken maxilliped 3, P1, P2, broken P3, P4, P5 (Fig. 3). Even though the specimen illustrated by Kobjakova [1936, 1937] is shown with all appendages on the left side intact, it likely corresponds to the specimen presently deposited in ZIN-RAS. For the purpose of taxonomic clarity we designate this specimen (ZIN-RAS 1/47346) as a lectotype. No indication of the presence of the other syntype (which becomes paralectotype) in the registered ZIN-RAS collection has been found.

The position and environmental characteristics of Stat. 258 were reported by Ushakov (1952: 27): $56^{\circ} 10^{\prime} \mathrm{N} 143^{\circ} 15^{\prime} \mathrm{E}$, gravel, stones, near bottom temperature $1.60{ }^{\circ} \mathrm{C}$, salinity $33.38 \mathrm{psu}, \mathrm{O}_{2}$ saturation $55 \%$.

OTHER MATERIAL. 1 female (ZMMU Ma-3563), Sea of Okhotsk, Iona Bank, F/V “Asanda”, 56 11 ,2' N 14316,6' E, 180 $\mathrm{m}$ (start of trawling $56^{\circ} 10,8^{\prime} \mathrm{N} 143^{\circ} 15,6^{\prime} \mathrm{E}-$ end of trawling $56^{\circ} 11,6^{\prime} \mathrm{N}-143^{\circ} 17,6^{\prime} \mathrm{E}$, between 200 and $160 \mathrm{~m}$ depth), near bottom temperature $0.8^{\circ} \mathrm{C}$. 12.08 .2017 , coll. S.E. Anosov.

DESCRIPTION (based on holotype and topotypic specimen). Adult female. Body moderately robust, integument smooth, without depressions on pleonal pleura (Figs. 2, 4a, 5). Rostrum (Figs 2, 3a, 4a, 6a) directed forward or slightly descending in middle and ascending in distal part, overreaching distal end of antennular peduncle, but not reaching distal margin of antennal scale, about 0.7 (in holotype; Figs $2,4 a)-0.65$ length of carapace. Dorsal margin armed with 6 (in holotype; Figs 2, 4a, 6a) - 5 (Figs 5b, 6b) sharp, directed forward subequal teeth in proximal 0.7 length, followed by a gap and 3 generally similar in shape postrostral teeth in anterior third of carapace. Ventral margin with narrow lamina in distal third, armed with 4 (in holotype; Figs 2, 6a) - 3 (Fig. 6b) teeth.

Middorsal carina moderately developed only in anterior part of carapace (Fig. 3a), last postrostral tooth somewhat stouter than others. Supraorbital tooth strong, arising from rostral base and nearly reaching to level of tip of proximal rostral tooth. Deep, generally V-shaped, but slightly curved notch inferior to base of supraorbital tooth (Figs 2, 6a, b). Postorbital region depressed. Suborbital lobe spiny. Antennal tooth triangular, short, not reaching beyond suborbital lobe. Anterolateral margin between antennal and pterygostomial teeth convex, rounded. Pterygostomial tooth sharp, slender, directed forward, reaching to or slightly overreach- ing level of suborbital lobe. Lateral ridges on carapace not developed (Figs 2, 4a, 5b).

Pleon dorsally rounded. First pleomere shortest, with straight anterolateral margin, dorsal face depressed in posterior third, ventral margin slightly convex. Pleuron of $2^{\text {nd }}$ pleomere longest, oval-shaped, broadly overlaps pleura 1 and 3, ventral margin rounded. Dorsal part of pleomere 3 robust, longest, pleuron shorter than dorsal part, rounded. Pleomere 4 with pleuron expanded ventro-posteriorly, with a small posteroventral spine. Fifth pleuron with sinuous posterior margin, terminating in a spine, and nearly straight ventral margin (Figs 2, 4a, 5b). Sixth pleomere about 1,8 times as long as fifth pleomere and about 2 times as long as high; posterodorsal margin straight, slightly produced (Figs $3 \mathrm{k}, 4 \mathrm{~b})$. Posterolateral process terminating in strong tooth; posteroventral angle with moderate tooth (Figs 2, 3k, 4b, 5b). Preanal plate reduced, preanal spine straight, triangular in ventral view, nearly reaching to posteromesial corners of uropodal protopods (Fig. 4d).

Telson (Figs 2k, 3b, 6g) about 1.7 times as long as sixth pleomere, about 3 times longer than maximal width, gradually narrowing posteriorly; dorsal surface broadly and shallow sulcate, dorsolateral ridge not expressed; with a row of 4 lateral spines on each side in distal half. Posterior margin nearly straight, with the following armature: a pair of spinules located laterally, a pair of larger spinules located mesiolaterally, and a pair of smaller spinules located medially, intermittent with sparse setae (Figs 3k, 6g).

Eye subpyriform, cornea large, darkly pigmented, its maximum diameter about 0.14 of carapace length. Eyestalk moderate, cup-shaped (Figs 2, 3a, 4a, 5). Antennular peduncle relatively slender, $1^{\text {st }}$ article little longer than next two articles combined, with a sharp ventrodistal spine at 4/5 of article length (Fig. 6c), and three spines on dorsolateral distal angle, mesial being shortest. Stylocerite symmetrical, terminating in long acute spine, reaching to about half of $2^{\text {nd }}$ article. Article 2 about 0.55 times as long as article 1, slightly broadened distally, armed with long slender spine at dorsolateral distal angle, reaching or nearly so to distal margin of article 3 . Article 3 short, with 2 spinules on dorsodistal margin. Lateral flagellum with thickened aesthetasc-bearing portion 0.30 times as long as carapace (Fig. 3a).

Antenna (Figs 5a, b, 6c) with robust basicerite, bearing sharp dorsolateral and ventrolateral spines. Antennal scale about 0.6 times as long as carapace, overreacing rostrum, about 2.8 times as long as wide; lateral margin convex, distolateral spine relatively slender, reaching distal margin of lamella. Carpocerite cylindrical, reaching about half of antennal scale.

Mouthparts not dissected. Maxilliped 1 and 2 with exopods and epipods. Maxilliped 3 (Figs 3b; 5b, c, 6c) moderate, far overreaching distal margin of antennal scale and slightly overeaching to antennular flagellae; ultimate article 4.7 times as long as penultimate article, setose, bearing 3-4 dark terminal spinules, 5-6 subterminal dorsomesial; spinules decreasing in size proximally, and 3-5 dorsolateral spiniles

Fig. 3. Lebbeus uschakovi. Lectotype, female (ZIN-RAS 1/47346): a — anterior part of the animal; b - third maxilliped, left, dorsal view; c - first pereiopod, right, dorsal view; d - second pereiopod, left; e — part of pereiopod 3; f — distal part of pereiopod 3; g — dactylus of pereiopod $3 ; \mathrm{h}$ - pereiopod 4 , left; $\mathrm{i}$ - dactylys of pereiopod $4 ; \mathrm{j}$ - pereiopod 5 , left; $\mathrm{k}$ - last two pleomeres and tail fan (telson and uropods). Drawing by B.G. Ivanov.

Рис. 3. Lebbeus uschakovi. Лектотип, самка (ЗИН РАН 1/47346): а - передняя часть креветки; b - максиллипед 3-й пары, левый, дорсальный вид; с - перейопод 1-й пары, правый, дорсальный вид; d - перейопод 2-й пары, левый; е - часть перейопода 3-й пары; f - дистальная часть перейопода 3-й пары; g - дактилоподит перейопода 3-й пары; $\mathrm{h}$ - перейопод 4-й пары, левый; i - дактилоподит перейопода 4-пой пары; j - перейопод 5-й пары, левый; $\mathrm{k}$ - пара задних сегментов абдомена и хвостовой веер (тельсон и уроподы). Рисунок Б.Г. Иванова. 


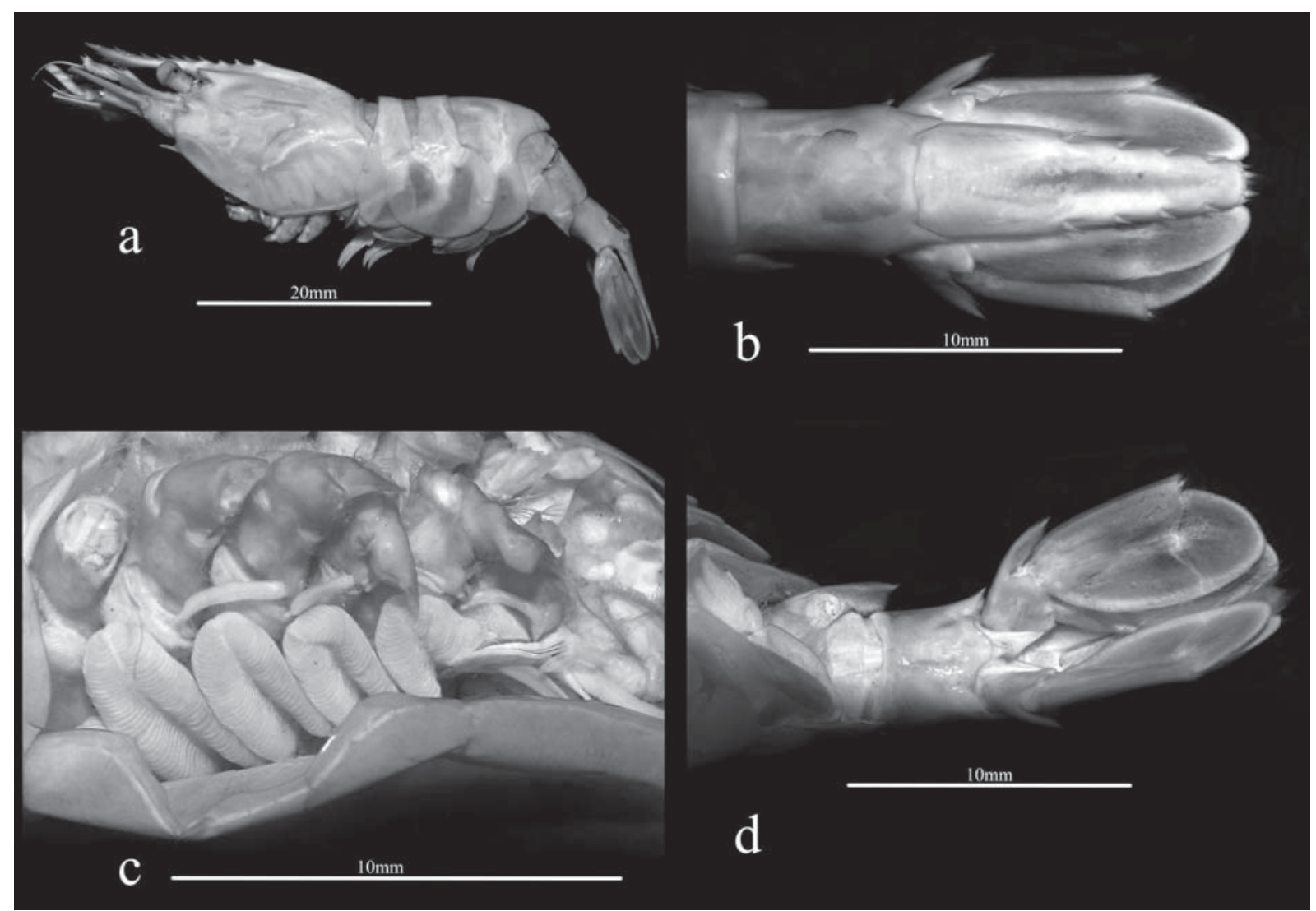

Fig. 4. Lebbeus uschakovi. Lectotype, ovigerous female (ZIN RAS 1/47346): a — entire specimen; b - last pleomere and tail fan, dorsal view; $\mathrm{c}$ - thoracopod coxae, branchiae and epipods; $\mathrm{d}$ - last pleomere, preanal plate and tail fan, ventral view. Photo by S.E. Anosov, September 2017.

Рис. 4. Lebbeus uschakovi. Лектотип, яйценосная самка (ЗИН РАН 1/47346): a — креветка целиком; b — последний сегмент абдомена и хвостовой веер, дорсальный вид; с — коксы торакопод, жабры и эпиподиты; $\mathrm{d}$ - последний сегмент абдомена, преанальная пластинка и хвостовой веер, вентральный вид. Фото С.Е. Аносова, сентябрь 2017 г.

(Fig. 6c). Penultimate article less setose. Antepenultimate article slightly shorter than distal two articles combined, with a pair of dorsolateral spinules on distal margin, lateral one being longer (Fig. 6c); exopod absent; coxa with terminally hooked epipod (Fig. $5 \mathrm{c}$ ).

P 1 (Figs 3c, 6d) relatively robust. Chela 1.8 times as long as carpus; dactylus about 0.6 times as long as palm, terminating in 3 corneous claws; fixed finger terminating in a strong claw; tips of both fingers beset with dense bunches of setae; bunches of setae laterally at articulation of dactylus and palm; palm about 2.86 as long as wide, covered by sparse setae. Carpus widened distally, slightly shorter than palm, with a distal sink at ventromesial margin, densely beset with setae (Fig. 6 c), representing grooming apparatus [Bauer, 1978]. Merus about 6.15 times as long as wide, sparsely setose, with a proximal spinule at ventrolateral corner, close to articulation with ischium and a row of setae on ventral margin. Ischium and basipodite with relatively long and dense setae on ventral margin and sparse setae on other surfaces. Terminally hooked epipod and setobranch present (Fig. 5c).

P2 (Figs 2d, 5a) moderately slender, overreaching antennal scale by length of chela and distal article of carpus, and reaching to tips of maxilliped 3. Chela about 0.2 times as long as carpus; dactylus about 0.5 times as long as palm with tufts of setae. Carpus subdivided into 7 articles, article
3 longest, occupying 0.3 times of whole carpal length; chela and distal 5 articles each with some tufts of setae. Merus about 1.2 times as long as ischium. Terminally hooked epipod and setobranch present (Fig. 5c).

P3 (Figs 3f, 5a-c) most robust of posterior three pereiopods, overreaching antennal scale by dactylus and propodus length (in lectotype) or little less; overreaching maxilliped 3. Dactylus (Fig. $3 \mathrm{~g}$ ) slender, 0.18 times as long as propodus, about 2 times longer than wide, terminating in a pair of moderate claws, subterminal one being smaller; 4 accessory spiniform setae diminishing in size proximally on flexor margin. Propodus about 10.5 times longer than wide, with 2 rows of thin and short spiniform setae on flexor margin and somewhat longer filamentous setae, mostly in groups by two-four on adductor margin (Fig. 3f). Carpus widened distally, about 0.6 times as long as propodus, 5 times as long as broad, unarmed but with 4 sparse rows of short filamentous setae, either singled or in groups of two to five. Merus little longer than propodus, 6.2 times as long as wide, armed with 7-9 strong spiniform setae increasing in size distally on lateral surface, and sparse filamentous setae, some in groups on other surfaces; ischium unarmed, with sparse filamentous setae. Terminally hooked epipod and setobranch present (Fig. 5c).

P4 (Figs 3h, 5a-c) similar to P3, but slenderer, overreaching antennal scale by less than half length of propodus; 


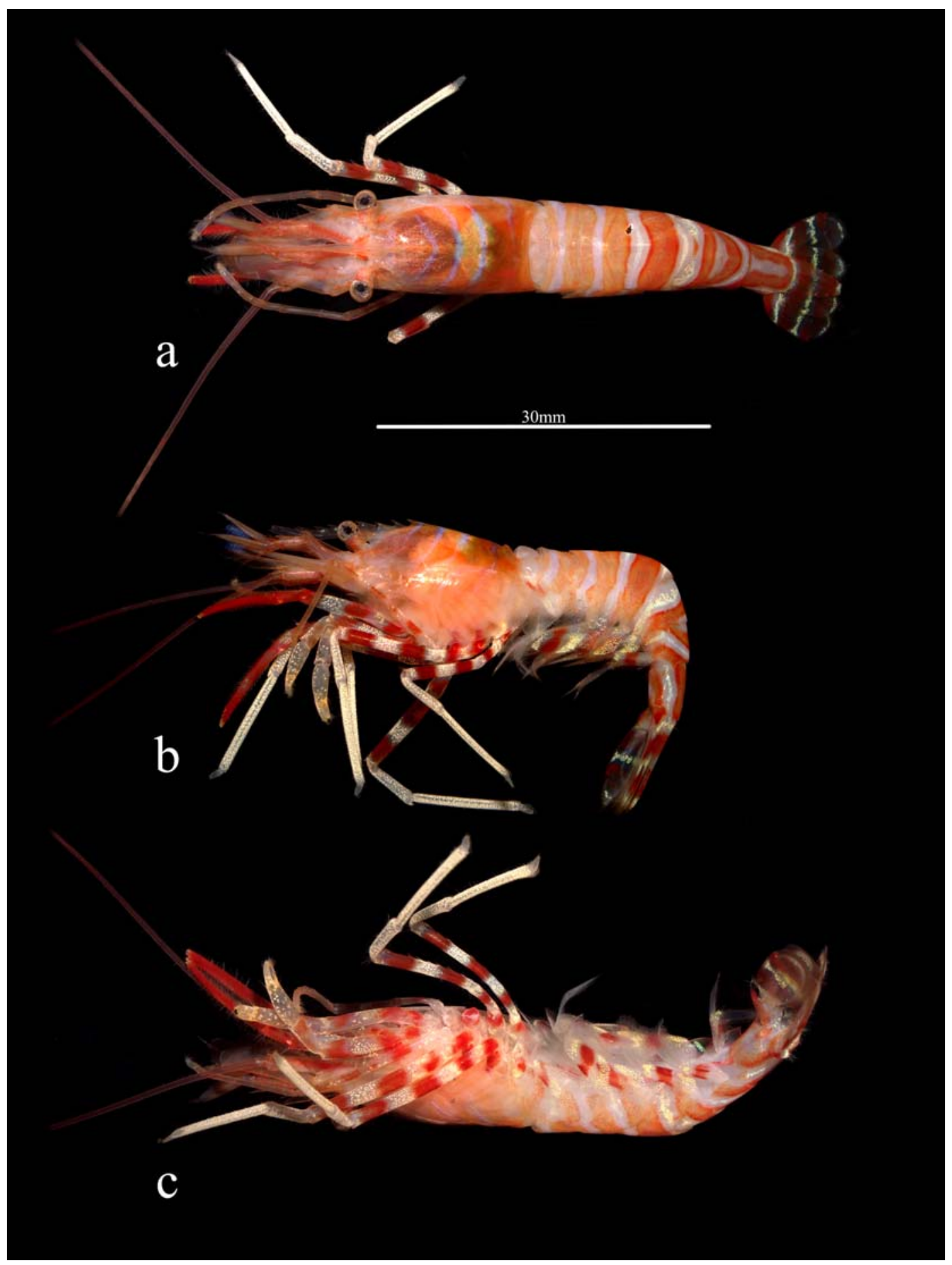

Fig. 5. Lebbeus uschakovi, specimen from topotypic locality, female; natural coloration (ZMMU Ma 3563): a — dorsal view; b lateral view; c - ventral view. Photo by S.E. Anosov.

Рис. 5. Lebbeus uschakovi, экземпляр из типового местонахождения, самка, естественная окраска (ZMMU Ma 3563): а дорсальный вид; b — латеральный вид; с — вентральный вид. Фото С.Е. Аносова.

dactylus with 4 accessory spiniform setae (Fig. 3i); merus with 7 spiniform setae on lateral surface (Fig. 3h). Epipod absent, setobranch present.

P5 (Fig. 3k, 4) generally similar to other pereiopods, overreaching antennal scale by length of dactylus, not reaching to maxillipeds; dactylus with 4 accessory spiniform setae; propodus with cluster of grooming setae on flexor sur- face distally; merus with 4-5 lateral spiniform setae. Epipod absent.

Pleopod 1 emarginated with thin and short filamentous setae, without appendix interna; protopod of pleopod 1 with well-developed lateral lobe, located nearly perpendicular to and overreaching mesial lobe, distal margin rounded; endopod leaf-like, about 3 times as long as broad; exopod about 5 


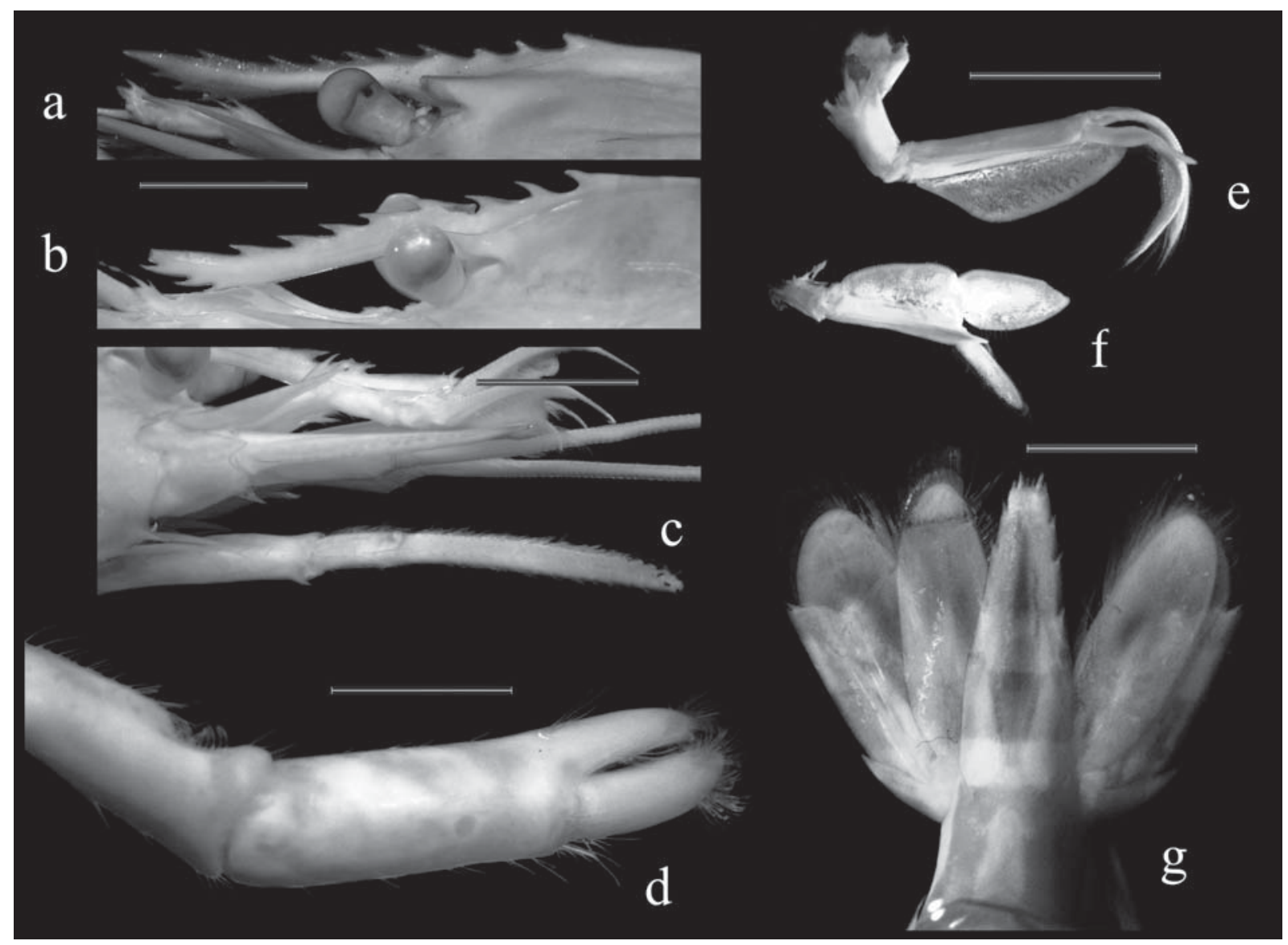

Fig. 6. Lebbeus uschakovi: a - lectotype; b-g — specimen from topotypic locality (ZMMU Ma-3563), female. a, b - rostrum and postrostral teeth; c — antennule, antenna, and maxiliiped 3 (lateral view); d - chela and carpus of pereiopod 1; e - pleopod 2; f — pleopod 1; g - tail fan, dorsal view. Scale: $5 \mathrm{~mm}$ (a, b, c, e, f), $1 \mathrm{~mm}$ (d). Macrophoto by V.A. Spiridonov.

Рис. 6. Lebbeus uschakovi: a - лектотип; b-g - экземпляр из типового местонахождения (ZMMU Ma-3563), самка. a, b рострум и постростральные зубцы; с - антеннула, антенна и максиллипед 3 (латеральный вид); d - клешня и карпоподит перейопода 1; е - плеопод 2; f — плеопод 1; g — хвостовой веер, дорсальный вид. Масштабная линейка: 5 мм , b, c, e, f), 1 мм (d). Макрофото В.А. Спиридонова.

times as long as broad (Fig. 6e). Pleopods $2-5$ similar to each other, emarginated with thin and short filamentous setae, with appendix interna reaching about half of exopod length; mesial lobe of protopod acuminated; endopod and exopod lanceolate, nearly equal, about 2.7 times as long as broad (Figs 2, 6f).

Branchial formula as summarized in Table 1.

Uropod with protopod terminating in acute spine posterolaterally; exopod subequal in length of endopod, both not reaching (not considering setal plume) or very slightly reaching beyond posterior end of telson (Figs $3 \mathrm{k}, 4 \mathrm{~b}, 6 \mathrm{~g}$ ).

COLORATION. Background carapace, pleon and telson coloration salmon pink; carapace with four transverse bluish stripes, oblique in lateral face. Spines not black-tipped. Mid parts of pleomeres 1-3 with transverse bands bluish-gray, with a mid-chain of pearly spotting. Similar band extends along posterior margin of pleomere 3 . Pleomere 4 with a distinctly broader band of similar pattern in anterior part but pearly spotting extending to respective pleura. Dorsal bluish-grayish bands at posterior margin of pleomere 4 and anterior margin of pleomere 5. Greyish-bluish band with pearly midline along posterior margin of pleomere 5 and extending obliquely along lateral faces. Three longitudinal bluish-greyish bands (1 dorsal and a pair of laterals) with scarce pearly spotting in pleomere 6 (Fig. 5). Sterna of all pleomeres whitish, except pleomere 6 and preanal spine being orange (Fig. $5 \mathrm{c}$ ).

Rostrum, antennules and antennes semi-transparent with orange pattern. Background coloration of maxilliped 3 and pereiopods semi-transparent greyish with dense pearly spotting. Ischia with one and meri with two transverse red bands. Ultimate and penultimate segments of maxilliped 3 red. Chela finger of $\mathrm{P} 1$ terminate in black spots. Caspus, propodus and chela of P 2 light orange (Fig. 5). Protopods of pleopods with oblique red and pearly bands, exopods and endopods transparent (Fig. 5b, c).

Telson and uropods (as a tail fan) dorsally with three transverse pearly bands with bluish emargination: along anterior margin of telson and posterior margins of uropods protopods, at mid-length, and along posterior margin of telson and uropods (Fig. 5a).

SIZE (in mm). Holotype measures: TL 62, CL 1 14.7, CL 2 18.5, CH 12.2, RL 10.5. Egg size $1.73 \pm 0.017 \times$ $1.26 \pm 0.01(1.6 \times 1.2-1.8 \times 1.3 ; \mathrm{n}=5)$. The specimen from the topotypic locality: TL 98.5, CL 119.5 , CL $225.0 ; \mathrm{CH}$ 13.5. 
Table 1. Arrangement of branchia on the thoracal appendages of Lebbeus uschakovi. Mxp - maxilliped. P — pereiopod. Таблица 1. Расположение жабер на торакальных конечностях Lebbeus uschakovi. Mxр - максиллипед.

Р - перейопод.

\begin{tabular}{|l|c|c|c|c|c|c|c|c|}
\hline \multirow{2}{*}{$\begin{array}{l}\text { Types of } \\
\text { branchia }\end{array}$} & \multicolumn{7}{|c|}{ Thoracal appendages } \\
\cline { 2 - 9 } & $\mathrm{mxp} 1$ & $\mathrm{mxp} 2$ & $\mathrm{mxp} 3$ & $\mathrm{P} 1$ & $\mathrm{P} 2$ & $\mathrm{P} 3$ & $\mathrm{P} 4$ & $\mathrm{P} 5$ \\
\hline Pleurobranch & 0 & 1 & 0 & 1 & 1 & 1 & 1 & 1 \\
\hline Arthrobranch & 0 & 0 & 0 & 0 & 0 & 0 & 0 & 0 \\
\hline Podobranch & 0 & 1 & 0 & 0 & 0 & 0 & 0 & 0 \\
\hline
\end{tabular}

AFFINITY. The concept of species group based on the presence of epipods on particular appendages has been traditionally applied to describe the internal diversity of the genus Lebbeus [Rathbun, 1904; Holthuis, 1947; Hayashi, 1992; Fransen, 1997]. Although it is not known if this division bears any phylogenetic significance, it proves to be useful for construction of keys and species identification. The present species belongs to the group with epipods present on the anterior three pereiopods (P1-P3), moderate to relatively long rostrum (reaching and overreaching $2^{\text {nd }}$ segment of antennal peduncle) in most species, and smooth margins of pleura 1-3. The group includes Lebbeus africanus Fransen, 1997 (continental slope off Mauritania, East Atlantic), L. bidentatus Zarenkov, 1976 (continental slope of Peru, East Atlantic); L. fasciatus (Kobjakova, 1936), shelf, N Pacific. L. indicus Holthuis, 1947 (continental slope, Bali Sea, Indonesia), L. ketophilos Nye, 2013 (seamount of SW Indian Ocean), L. speciosus (Urita, 1942) (shallow subtidal, NW Pacific), and L. washingtonianus (Rathbun, 1902) (continental slope of NE Pacific).

The present species is most similar to L. bidentatus, which is, however, known only from the male holotype, and $L$. washingtonianus. The two species have been considered vicariant races by Wicksten and Méndez [1982]. The available distinguishing characters of $L$. uschakovi are listed below:

- the presence of 5-6 dorsal rostral teeth vs. 4 teeth in $L$. bidentatus and 3 teeth in L. washingtonianus;

- the presence of 3 postrostral teeth vs. a single tooth in L. bidentatus [Fransen, 1997, fig 30], and 1-2 teeth in $L$. washingtonianus;

- sixth pleomere about 1,8 times as long as $5^{\text {th }}$ pleomere vs. 1.5 times as long;

- the basal article of antennular peduncle reaching to half of the scaphocerite length vs. reaching to less than half of the scaphocerite length in the compared species;

- three vs. five spines on the posterior margin of telson;

-2 distal spines vs. 1 spine on the $3^{\text {rd }}$ article of antennular peduncle.

From L. washingtonianus L. uschakovi also differs by a longer rostrum which in the first species is reaching only to the margin of the basal article of antennular peduncle.

Lebbeus uschakovi is in many characters similar to $L$. africanus but differs from that species in the following:

- the rostrum being slenderer [compare Fig. 2 and Fransen, 1997, figs 2, 27-29];

- more numerous rostral spines of the female (5-6 vs. 23 dorsal teeth, 3-4 vs. 2 ventral teeth);

-3 vs. $2-3$ postrostral teeth;

- the sixth pleomere about 1,8 times as long as the $5^{\text {th }}$ pleomere vs. 1.5 times as long;

- the stylocerite reaching to about half-length of the $2^{\text {nd }}$ article of antennular peduncle vs. reaching only the margin of basal peduncle [Fransen, 1997, fig. 3];
- the posteroventral corner of $4^{\text {th }}$ pleuron spinulated vs. rounded;

- three vs. five pairs of spines on the posterior margin of telson;

- fewer number of strong spiniform setae on the lateral surface of pereiopod meri, 7-9 vs. 5 on the $3^{\text {rd }}$ pereiopod, 45 vs. 2 on the $4^{\text {th }}$, and $4-5$ vs. 0 on the $5^{\text {th }}$ pereiopod.

Lebbeus fasciatus and L. speciosus are shallow water species with complicated synomymy and overlapping distribution, which can be distinguished by relative length of the $3^{\text {rd }}$ maxilliped and coloration pattern [Hayashi, 1992]. L. uschakovi differs from these species by a narrow (Fig. 1) vs. relatively broad [Hayashi, 1992, figs 4, 13] ventral lamina of the rostrum; by continuous row of teeth along the anterior margin of carapace and the dorsal margin of the rostrum vs. a gap between the rostral and the postrostral teeth; by the presence of middorsal carina in the anterior part of carapace vs. a not-carinated carapace in both shallow water species; by a weakly rounded, nearly straight vs. angled posterior margin of telson with 6 ( 3 pairs) of spines and spinules, vs. 8 (4 pairs) in L. fasciatus and 7 spines, including the median one in L. speciosus [Hayashi, 1992, fig. 14a]; by distinctly slenderer pereiopods 1, and 3-5 [Hayashi, 1992, figs 4, 13].

Lebbeus ketophilos has been described upon a single male holotype, while for L. uschakovi only females are currently available. Males of Lebbeus usually have fewer teeth on the rostrum [Menshutkina, 1987]. The male of $L$. ketophilos does not have dorsal rostral teeth [Nye, 2013, fig. 2B] while the number of these teeth in females is unknown. Even though, L. uschakovi is readily distinguishable from $L$. ketophilos by the following characters:

- rostrum not markedly upcurved and not reaching vs. reaching the margin of antennal scale;

$-3-4$ ventral teeth of the rostrum vs. 5 teeth;

-3 vs. 2 dorsolateral spines of the $1^{\text {st }}$ article of antennular peduncle;

- telson about 1.7 times vs. 1.3 times longer than the $6^{\text {th }}$ pleomere, with weakly rounded vs. markedly rounded posterior margin [Nye, 2013, fig. 2E];

-2 distal spines vs. 1 spine on the $3^{\text {rd }}$ article of antennular peduncle;

$-7-9$ strong spiniform setae on the lateral surface of $3^{\text {rd }}$ pereiopod merus vs. 4-5 spiniform setae;

$-4-5$ strong spiniform setae on the lateral surface of $5^{\text {th }}$ pereiopod merus vs. 1 seta;

- uropods not reaching vs. reaching [Nye, 2013, fig. 2D] beyond posterior end of telson.

Lebbeus uschakovi also differs from $L$. indicus [see Holthuis, 1947, figs 1-3] by a not markedly upcurved rostrum, more numerous dorsal (5-6 vs. 2 ) and fewer ventral spines of the rostrum (3-4 vs. 6$)$, and the following characters:

- the posteroventral corner of $4^{\text {th }}$ pleuron spinulated vs. rounded; 
-7-9 strong spiniform setae on the lateral surface of $3^{\text {rd }}$ pereiopod merus vs. 6 spiniform setae;

-4-5 strong spiniform setae on the lateral surface of $5^{\text {th }}$ pereiopod merus vs. 2 setae.

ECOLOGY. Lower shelf species (200-160 m) with a possible preference to hard bottom; recorded so far at positive near bottom temperature $\left(0,8-1.6{ }^{\circ} \mathrm{C}\right)$.

DISTRIBUTION. So far known only from Iona Bank in the Sea of Okhotsk.

\section{Discussion}

Lebbeus uschakovi was described on the basis of two specimens from a single trawl sample obtained at Iona Bank in the northwestern Sea of Okhotsk. The species remained hidden for researchers for the next decades. It had not been recorded in the subsequent decapods surveys of 1930-1950-s [Vinogradov, 1950; Kobjakova, 1955, 1962] nor in the recent detailed studies of West Kamchatka shelf [Sokolov, 2001] and the northern Sea of Okhotsk [Bandurin, Karpinsky, 2015], but it was surprisingly found in the nearly same locality, and in the same season after 85 years passing since the first record. This indicates $L$. uschakovi to be at least rare in the Sea of Okhotsk in general but probably relatively common in its type locality.

An extensive shallow around Iona I. and the neighboring large Kashevarov Bank are characterized by peculiar conditions. Sediments are dominated by gravel, pebble and boulders while in surrounding waters muddy sediments predominate at corresponding depth [Bezrukov, 1960; Rogachev et al., 2000]. This is the area of strong tidal currents that produce deep mixing involving the subsurface cold Okhotsk water mass which core contacts the seabed at the banks; another consequence of this process is cooling of surface layers [Rogachev et al., 2000; Luchin, Kruts, 2016]. On the other hand, tidal mixing leads to positive near bottom temperature in the type locality of L. uschakovi in summer $\left(0.8-1.60^{\circ} \mathrm{C}\right)$ while many other shelf areas at similar depth (100-200 m) in the Sea of Okhotsk fall within the belt of round year negative temperature associated with the minimum layer [Moroshkin, 1966]. A generally high productivity of the area [Shuntov, 2001] is also indicated by abundant seabird colonies at Iona I., about 300 thousand specimens, about half of them being thick-billed murres, Uria lomvia (L., 1758) [Kharitonov, 2007]. Benthic communities on hard bottom are strongly dominated by epifaunal sestone feeders [Savilov, 1961]. Such benthic biotopes and communities are patchily distributed in the Sea of Okhotsk [Savilov, 1961; Shuntov, 2001; Malyutin, 2015].

Lebbeus uschakovi may therefore be a specialized species, adapted to particular conditions of hard bottom biotopes with strong near bottom currents and rich epifauna. Taking into account ability of Lebbeus species to form association with cnidarians [Jonsson et al., 2001; Schiaparelli et al., 2015] we can't exclude that $L$. uschakovi also maintains commensal or symbiotic relationships with some epifaunal taxa. Effective collect- ing of Lebbeus species which have specialized modes of life requires targeted sampling (as partly applied in the present study) and even special methods, i.e. remotely operated vehicles [Nye, Copley, 2014; Schiaparelli et al., 2015] or whale-bone mooring [Nye, 2013], because their biotopes may be difficult for applying conventional gears.

Outside of the Iona Bank Lebbeus uschakovi is expected to occur at the Kashevarov Bank to the east of Iona I., the area with similar oceanographical and sedimenthological setting, which require special studies and protection due to its unique environment and yet very poorly known benthic biodiversity [Malyutin, 2015]. Other biotopes with hard substrates, strong near bottom currents and abundant gorgonarians, stylasterid hydrocorals, bryozoans, and sponges are located at shelf break and slopes of both Okhotsk and Pacific sides of Kuril Islands [Sirenko, 1993; Malyutin, 2015] but are generally deeper (Fig. 1). Hard substrate biotopes with rich epifauna on the northwestern Kamchatka shelf [Savilov, 1961; Shuntov, 2001] are influenced by the cold layer of the Okhotsk water mass.

Several species of Lebbeus are known to have particularly large eggs [Hendrickx, 2001; Nye, Copley, 2014; Sedova, Grigoriev, 2016]. For example, in $L$. polaris (Sabine, 1824) fertilized eggs are distinctly larger than in several other studied high latitude caridean species [Clark, 1996]. Only in two species, Lebbeus groenlandicus (Fabricius, 1775) and L. polaris larval development has been studied by means of rearing: they are characterized by fewer (2-3) number of zoea stages than any other genera of Thoridae and related families [Haynes, 1981; Terossi et al., 2010]. The first stage of zoea larvae of Lebbeus are morphologically more advanced than sympatric species of Eualus and Spirontocaris [Haynes, 1981; Sedova, Grigoriev, 2016]. The larvae of Lebbeus spp. with abbreviated development are also not commonly found in plankton surveys [Sedova, Grigoriev, 2016]. Similarly to its congeners L. uschakovi has very large eggs (nearly $2 \mathrm{~mm}$ in longer dimension) associated with relatively low actual fecundity (a probably incomplete clutch of about 180 eggs). This indicates an abbreviated larval development with limited capacity of larval dispersal and connectivity between populations inhabiting suitable for species spatially separated habitats. Currently it is not even known if such multiple populations exist within the Sea of Okhotsk outside the Iona Bank, not to say about other seas. In the neighboring areas, i.e. the northern Sea of Japan shelf in the south-west, and the narrow South-East Kamchatka shelf in the north-west, the habitats suitable for the present species are hardly expected to be found [Shuntov, 2001]. L. uschakovi may thus represent a true endemic species with restricted distribution in the Sea of Okhotsk.

\section{Acknowledgements}

The authors are deeply obliged to Master P.V. Filatov and the crew of F/V "Asanda" for their support during the exploratory survey and the MAGADAN- 
RYBA group for organization of the field work. We thank Dr. Victor V. Petryashov (ZIN RAS) for his generous help in working with Z.I. Kobjakova's types and other material deposited in the Zoological Institute of the Russian Academy of Sciences, St. Petersburg and Dr. Dmitry O. Alexeev for maintaining the archive of the unforgettable senior colleague Boris Ivanov in VNIRO. This study is part of the Russian Foundation for Basic Research (RFBR) project 16-04-01526 A "Scale and patterns of endemism of the Crustacea Decapoda in the seas of Russia".

\section{References}

Bandurin K.V., Karpinsky M.G. 2015. [Shrimps and prawns of the northern part of the Sea of Okhotsk]. Moscow: VNIRO Publishing. ISBN 978-5-85382-459-1. 214 p. [in Russian]

Bauer R.T. 1978. Antifouling adaptations of caridean shrimps: cleaning of the antennal flagellum and general body grooming // Marine Biology. Vol.49. P.69-82.

Bezrukov P.L. 1960. [Bottom sediments of the Sea of Okhotsk] // Trudy Instituta Okeanologii AN SSSR. Vol.32. P.15- 95 [in Russian].

Birstein Ya.A., Vinogradov L.G. 1951. [New and rare species of decapods crustaceans of the Sea of Okhotsk and waters of Kuril Islands] // Doklady Akademii Nauk SSSR. Vol.79. P.357360 [in Russian].

Brandt J.F. 1851. Krebse // Dr. A. Th. von Middendorffs Reise in den äussersten Norden und Osten Sibiriens. Band 2. Theil 1. St.Petersburg: Buchdruckerei der Academie der Wissenschaft, S.79-148. Taf.1-5.

Brazhnikov V.K. 1907. [Material on the fauna of Russian Eastern seas collected on board schooner "Storozh" in 1899-1902] // Zapiski Rossiyskoi Imperatorskoi Akademii Nauk [Letters of Russian Imperial Academy of Sciences]. Vol.20. No.6. P.1185 [in Russian].

Butler T.H. 1980. Shrimps of the Pacific Coast of Canada // Canadian Bulletin of Fishery and Aquatic Sciences. Vol.202. P.1280.

Chan T-Y., Komai T. 2017. A new shrimp species of the genus Lebbeus White, 1847 (Crustacea: Deacpoda: Caridea: Thoridae) from a deep-sea cold seep site off southwestern Taiwan // Zootaxa. Vol.4238. P.426-432.

Clarke A. 1996. Marine benthic populations in Antarctica: patterns and processes // Antarctic Research Series. Vol.70. P.373-388.

De Grave S., Fransen C.H.J.M. 2011. Carideorum catalogus: the recent species of the dendrobranchiate, stenopodidean, procarididean and caridean shrimps // Zoologische Mededelingen. Vol.85. P.195-588.

Fransen C.H.J.M. 1997. Lebbeus africanus spec, nov., a new shrimp (Crustacea, Decapoda, Caridea, Hippolytidae) from Mauritanian waters, with redescriptions of four other species in the genus // Zoologische Mededelingen Leiden. Vol.71. P.231260.

Hayashi K. 1992. Studies on the hippolytid shrimps from Japan VIII. The genus Lebbeus White // Journal of Shimonoseki University Fisheries. Vol.40. P.107-138.

Haynes E. 1981. Early zoea stages of Lebbeus polaris, Eualus suckleyi, E. fabricii, Spirontocaris arquata, S. ochotensis, and Heptacarpus camtschaticus (Crustacea, Decapoda, Caridea, Hippolytidae) and morphological characterization of zoea of Spirontocaris and related genera // Fishery Bulletin. Vol.79. P.421-440.

Hendrickx M. 2001. Occurrence of a continental slope decapod crustacean community along the edge of the minimum oxygen zone in the south eastern Gulf of California, Mexico // Belgian Journal of Zoology. Vol.131. Suppl.2. P.95-110.

Holthuis L.B. 1947. The Hippolytidae and Rhynchocinetidae collected by the Siboga and Snellius Expeditions with remarks on other species // Siboga Expeditie Monographs. Vol.39a8. P.1100.

International Commission on Zoological Nomenclature. 1999.International Code of Zoological Nomenclature. Fourth Edition.London: International Trust for Zoological Nomenclature. $306 \mathrm{p}$.

Jonsson L.G., Lundälv T., Johannesson K. 2001. Symbiotic associations between anthozoans and crustaceans in a temperate coastal area // Marine Ecology Progress Series. Vol.209. P.189195.

Kharitonov S.P. 2007. [On the birds of Iona Island] // Russian Ornithological Journal. Vol.26. Express issue 1504. P.40704076 [in Russian].

Kobjakova Z.I. 1936. [Zoogeographical review of the Decapoda fauna of the Sea of Okhotsk and the Sea of Japan] // Trudy Leningradskogo obschestva estestvoispyatatelei. Vol.65. Issue 2. P.185-228 [in Russian].

Kobjakova Z.I. 1937. [ Decapod crustaceans of the Sea of Okhotsk and the Sea of Japan // Uchenye zapiski Leningradskoo gosudarstvennogo universiteta. Vol.15. P.93-154 [in Russian].

Kobjakova Z.I. 1955. [New species of Crustacea Decapoda from the southern part of the Kurile-Sakhalin area] // Trudy Zoologicheskogo Instituta Akademii Nauk SSSR. Vol.18. P.235-242 [in Russian].

Kobjakova Z.I. 1962. [Notes on rare and new species of decapod crustaceans (Decapoda, Malacostraca) from the region of Kuril Islands] // Issledovaniya Dalnevostochnykh Morei SSSR. Issue 8. P.243-247 [in Russian].

Komai T. 1997. A review of the Metacrangon jacqueti group, with descriptions of two new species (Decapoda, Caridea, Crangonidae) // Zoosystema. Vol.19. P.651-681.

Komai T. 2015. Reinstatement and redescription of Lebbeus armatus (Owen, 1839), long synonymized with L. groenlandicus (Fabricius, 1775), and description of one new species from the southwestern Sea of Okhotsk, Hokkaido, Japan (Crustacea: Decapoda: Caridea: Thoridae) // Zootaxa. Vol.3905. P.451473.

Komai T., Amaoka K. 1989. Records of some rare deep-sea decapods crustaceans from the Okhotsk Coast of Hokkaido // Bulletin of the Faculty of Fisheries, Hokkaido University. Vol.40. No.4. P.278-291.

Komai T., Eletskaya M. 2008. A new species of the pandalid shrimp genus Pandalus (Crustacea: Decapoda: Caridea) from the Sea of Okhotsk off eastern Sakhalin, Russian Far East // Zootaxa. Vol.1882. P.46-56.

Komai T., Komatsu H. 2009. Deep-sea shrimps and lobsters (Crustacea: Decapoda) from Northern Japan, collected during the Project "Research on Deep-sea Fauna and Pollutants off Pacific Coast of Northern Japan" // Fujita T. (ed.). Deep Sea Fauna and Pollutants off Pacific Coast of Northern Japan. National Museum of Nature and Science Monographs. No.39. P.495580.

Komai T., Matsuzaki K.. Hibino M. 2016. Rediscovery and redescription of a deep-sea shrimp Lebbeus longidactylus (Kobjakova, 1936) (Crustacea: Decapoda: Caridea: Thoridae) based on material from the Nemuro Strait, southwestern Sea Okhotsk // Zootaxa. Vol.4175. P.390-400.

Komai T., Yakovlev Yu.M. 2000. Decapod crustaceans collected during the Biological Expedition to the Kamchatka Peninsula and the North Kuril Islands in 1997 // Natural History Research. Special Issue No.7. P.301-322.

Luchin V.A., Kruts A.A. 2016. [Properties of core water masses in the Okhotsk Sea] // Izvestia TINRO. Vol.184. P.204-218 [in Russian].

Malyutin A.N. 2015. Deep-sea (cold-water) coral communities of the North Pacific and problems of their conservation // Russian Journal of Marine Biology. Vol.41. P.1-9.

Marin I.N. 2013. [Atlas of Decapod Crustaceans of Russia]. Moscow: KMK Scientific Press. 145 p. [in Russian]

Matsuzaki K., Hibino M., Komai T. 2015 A new species of the caridean shrimp genus Lebbeus White, 1847 (Crustacea: Decapoda: Thoridae) from the southwestern Sea of Okhotsk, Hokkaido, Japan // Zootaxa. Vol.4032. No.3. P.309-318. 
McLaughlin P.A. 1980. Comparative morphology of recent Crustacea. San Francisco: W.H. Freeman and Company. 177 p.

Menshutkina T.V. 1987. [Interspecific variability of shrimps Lebbeus polaris (Sabine) and Lebbeus pauli (Brandt) in different parts of the distribution range] // Alexeev A.P., Skarlato O.A., Lubimova T.G. (eds.). Biologicheskie resursy Arktiki i Antarktiki. Moscow: Nauka. P.138-149 [in Russian].

Moroshkin K.V. 1966. [Water masses of the Sea of Okhotsk]. Moscow: Nauka. 67 p. [in Russian]

Nye V. 2013. New species of hippolytid shrimps (Crustacea: Decapoda: Caridea: Hippolytidae) from a southwest Indian Ocean seamount // Zootaxa. Vol.3637. P.101-112.

Nye V., Copley J., Plouviez S., Van Dover C.L. 2013. A new species of Lebbeus (Crustacea: Decapoda: Caridea: Hippolytidae) from the Von Damm Vent Field, Caribbean Sea // Journal of the Marine Biological Association of the United Kingdom. Vol.93. No.3. P.741-751.

Nye V., Copley J. 2014. Reproductive ecology of a hippolytid shrimp, Lebbeus virentova (Caridea: Hippolytidae) at the Von Damm Vent Field, Mid-Cayman Spreading Centre // Marine Biology. Vol.161. P.2371-2380. doi:10.1007/s00227-0142512-9.

Rathbun M.J. 1902. Descriptions of new decapod crustaceans from the west coast of North America // Proceedings of the United States National Museum. Vol.24. No.1272. P.885-905.

Rathbun M.J. 1904. Decapod crustaceans of the northwest coast of North America // Harriman Alaska Expedition. Vol.10. P.1190, plates $1-10$.

Rogachev K.A., Carmack E.C., Salomatin A.S. 2000. Strong tidal mixing and ventilation of cold intermediate water at Kashevarov Bank, Sea of Okhotsk // Journal of Oceanography. Vol.56. P.439-447.

Savilov A.I. 1961. [Ecological characteristics of bottom invertebrates communities in the Sea of Okhotsk] // Trudy Instituta Okeanologii AN SSSR. Vol.46. P.3-84 [in Russian].

Schiaparelli S., Ahyong S.T., Bowden D. 2015. Evidence of niche conservatism and host fidelity in the polar shrimp Lebbeus kiae n. sp. (Decapoda: Caridea: Thoridae) from the Ross Sea, Antarctica // Hydrobiologia. Vol.761. P.45-69. doi.org/10.1007/ s10750-015-2403-1

Sedova N.A., Grigoriev S.S. 2016. [A guide for identification of families and stages of development of shrimp larvae of Kamchatka and adjacent waters] // Vestnik Kamchatskogo gosu- darstvennogo tekhnicheskogo universiteta. Vol.37. P.77-84 [in Russian].

Shuntov V.P. 2001. [Biology of Far-Eastern Seas of Russia]. Vladivostok: Pacific Researh Fisheries Centre (TINRO) Publishing. 579 p. [in Russian]

Sirenko B.I. 1993. [Distribution of benthos in some areas of continental slope of the Kuril Islands chain] // [The Fauna of the Continental Slope of the Kuril Island Chain). Issledovaniya morei. Vol.46(54). Saint Petersburg: Zoological Institute of Russian Academy of Sciences. P.5-44 [in Russian].

Sokolov V.I. 2001. Decapod crustaceans of the Southwest Kamchatka shelf: R/V "Professor Levanidov" collections in 1996 // Arthropoda Selecta. Vol.10. No.2. P.103-136.

Spiridonov V.A. 1993. The preanal plate and spine of Euphausiacea (Crustacea), their variability and homology (with particular reference to the austral species of the genus Euphausia Dana) // Arthropoda Selecta. Vol.1 (for 1992). No.4. P.3-15.

Spiridonov V.A., Petryashov V.V., Marin I.N. 2013. Order Decapoda // Sirenko B.I. (ed.) Check-list of species of free-living invertebrates of the Russian Far Eastern seas. Issledovaniya fauny morei. Vol.75(83). St. Petersburg: Zoological Institute of Russian Academy of Sciences. P.116-118.

Terossi M., Cuesta J.A., Wehrtmann I.S., Mantelatto F.L. 2010. Revision of the larval morphology (Zoea I) of the family Hippolytidae (Decapoda, Caridea), with a description of the first stage of the shrimp Hippolyte obliquimanus Dana, 1852 // Zootaxa. Vol.2624. P.49-66.

Ushakov P.V. 1952. [Fauna of the Sea of Okhotsk and conditions of its existence]. Leningrad: AN SSSR Publ. 459 p. [in Russian]

Vinogradov L.G. 1950. [Key to identification of shrimps, crayfish, and crabs of the Far East] // Izvestia TINRO. Vol.33. P.179358 [in Russian].

Wicksten M.K., Méndez M. 1982. New records and new species of Lebbeus (Caridea: Hippolytidae) from the Eastern Pacific Ocean // Bulletin of Southern California Academy of Sciences. Vol.81. P.106-120.

WORMS (World Register of Marine Species). 2018. Lebbeus White, 1847. http://www.marinespecies.org/aphia.php?p=taxdetails\&id= 106989. Last access 13.01.2018.

Responsible editor K.G. Mikhailov 